\title{
Chapter 3 \\ Making Cosmopolitan Spaces: Urban Design, Ideology and Power
}

\author{
Giovanni Semi
}

\subsection{Introduction}

The diffusion of signature architecture, flagship projects and the making of a global architect stardom system indicates the relevance of place-making activities within contemporary urbanism (King 2004; Ponzini and Nastasi 2016; Alaily-Mattar et al. 2020). This reflects the transformations of capitalism, in its productive and spatial shape: on one hand, urbanization is the productive side of capitalism, a real estating of the world, and, on the other, the most attractive investment locations are nowadays found in China, the Arabian Peninsula and in the highest echelon of the urban hierarchy, global cities (Rossi 2017).

Mobile urbanisms and fast policy regimes are spreading and different professionals work beyond the (urban) scenes (McCann and Ward 2011; Peck and Theodore 2010, 2015). Beside the most obvious "place entrepreneurs" (developers, real estate agents, financial institutions, companies and public actors), there is a whole world of expertise that deserves closer scrutiny. This chapter is devoted to urban designers, one of the most relevant yet ambiguous professional groups within the urban realm (Schurch 1999), and the ways through which they apply cosmopolitan visions through their practices.

In this chapter I will argue that we are witnessing a growing interest for both the notion and production of public space, which is largely addressed by urban designers, who function as the key professionals in making cosmopolitan spaces (Madanipour 2006). The core of the chapter is devoted to an analysis of the field of urban design from qualitative data on the making of a global elite of urban professionals. These data are drawn from research on practitioners and academics carried out in different cities and contexts in the US (New York, Chicago, San Francisco)

G. Semi $(\bowtie)$

Università degli Studi di Torino, Torino, TO, Italy

e-mail: giovanni.semi@unito.it 
and Europe (London, Edinburgh, Newcastle, Berlin, Amsterdam, Delft, Haarlem, Rotterdam, Utrecht, Copenhagen and Stockholm).

\subsection{Urban Design Meets the Public Space}

The rise of signature buildings, flagship projects and "starchitecture" has boosted the visibility and commitment of urban design as a support for built environment interventions (Ponzini 2014; Ponzini and Nastasi 2016; Sklair 2005) within a frame of "cosmopolitan urbanism" (Binnie et al. 2006). This specific and growing demand for place-making activities has coalesced around a typical urban setting: the public space (Gospodini 2002; Madanipour 2006; Sorkin 2009). The development of urban design as a "way of thinking" (Marshall 2009, 55) between practice and theory, firms and academia, is thus related to the specific historical imprint to urban design offered by architects and their curriculum (Mumford 2009). At the same time, urban design has profited from the changed landscape of space production.

The primacy of urban design in the contemporary production of space is thus particularly evident in streets, squares, parks, waterfronts, as well as in masterplans, large-scale interventions and urban regeneration activities. We have chosen to focus on the relationship between urban design and the production of contemporary public spaces for two essential reasons: the quintessential urban nature of the latter as cosmopolitan places and their problematic and puzzling nature as open spaces.

\subsubsection{The Public and the Private}

Often viewed in opposition with private spaces, public spaces are highly regulated, precisely because of their challenging non-private essence. Rights of entry, entitlements, rules of proper behavior and the constant definition of order are at the basis of such spaces. Regulations are the rule, not the exception, and it follows that politics and conflicts are an essential part of the deal, framing the artificiality of the public space (Amin 2008).

As shown in the following graph, even though the Western world has a millennium-long experience and knowledge of public spaces, they are very recent urban objects of desire and inquiry (Bodnar 2015). 


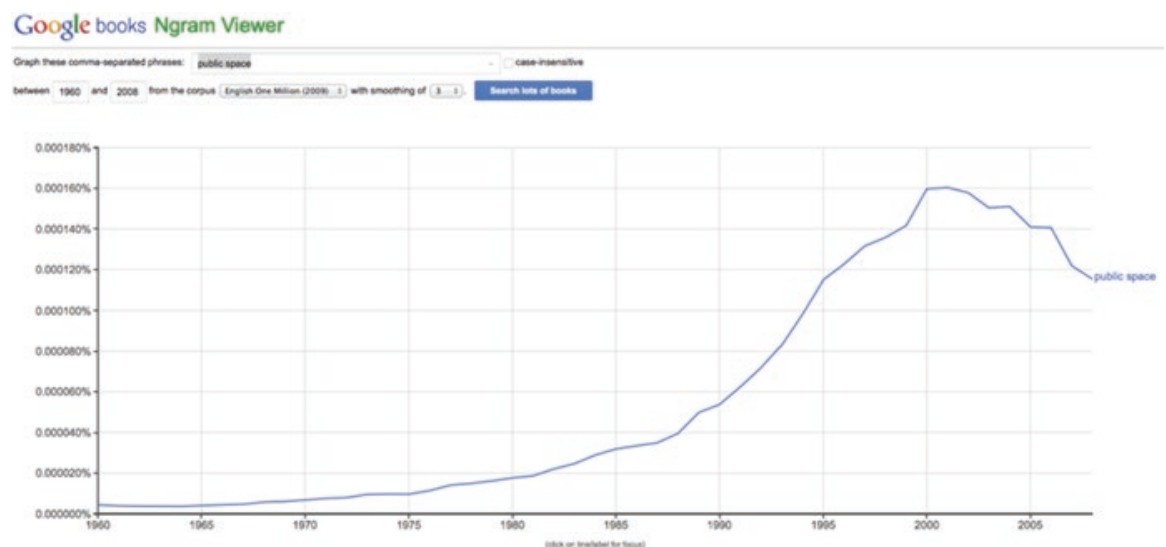

The growth in Anglo-American books on such spaces is telling. The golden age of public space discourse is thus very recent, starting mostly in the 1980s, when neoliberal policies were rapidly substituting postwar social contracts with the dismantling of the Keynesian welfare system (Jessop 1993). Moreover, the fact that this rise of consideration for public spaces has accompanied the growth of placemaking interventions does not contradict the contemporaneous view eulogizing the end of the public space (Sorkin 1992). That view simply acknowledged the death of the romantic vision of urban life, à la Jacobs or Lefebvre, and longed for authentic encounters in the urban realm. Such places may be called oppositional public places, in contrast to what emerged from the 1980s onwards - festive public spaces, to follow Mitchell $(2003,138)$. Festive public places were highly promoted by neoliberal policies during the third and fourth waves of gentrification (Hackworth and Smith 2001; Lees et al. 2013; Semi 2015) and, in general, through most regeneration interventions in the deindustrialized Western urban landscape (Hubbard 1996; Harvey 2011; Moulaert et al. 2003). The elements of these new spaces are wellknown: "Corporate and state planners have created environments that are based on a desire for security more than interaction, for entertainment more than (perhaps divisive) politics" (Mitchell 2003, 138; see also Hannigan 2005; Julier 2005; Zukin 1995). Beside the securitarian aspect, in which the technologies of CCTV and GPS have also contributed to reshaping the physical and spatial experience of gatherings (Graham and Marvin 2001), the most evident element of festive public places is in the transformed façade of the visible urban landscape: lighting, sidewalks, shop windows as well as the built environment as such.

The festive city, with its transformed rhythms, is a matter of capitals and political choices; urban design may be considered one of the multiple sites through which we may observe its making. The public space thus becomes the friendly and cosmopolitan milieu reassuring these generations of young, educated urban middle classes on their locational choices (Young et al. 2006). This public space is built on a striking paradox: it is designed and manufactured by sanitizing any kind of conflict in order to generate a disciplined sociability, apolitical and friendly, secure and vibrant. 
Architecture, landscape architecture and urban design play a pivotal role here: they transform such political projects into urbanism or, to quote Michael Sorkin, "urban design became urban renewal with a human face" $(2009,166)$.

\subsection{Desire and Design}

In the last few decades, as we have seen, public space has gained a higher profile, and so too have those producing it. Who are the people involved in producing public space, and, more specifically, in producing the built urban environment that is "between the buildings" (Gehl 2011)? We may include within this group a large number of actors: architects, urban designers, planners, academics, local authorities and, of course, residents and city-users.

A mainly qualitative approach has been chosen to investigate these issues. A number of semi-structured interviews were conducted with two different sets of actors: (1) people working in firms that produce projects or visions of urban design for public or private clients, and (2) people involved in university programs that teach or carry out research within urban design, and therefore produce knowledge across the field and train the next generation of urban designers (see also Semi and Bolzoni 2020). The sample was built on an international basis, including cases from Europe and the USA. ${ }^{1}$ Among the many results stemming from the interviews, an important one concerns the contradiction between the design of a public space often thought of as a cosmopolitan, democratic urban device and the hard fact of working in non-democratic environments or, to say the least, under critical conditions.

The first element of the survey dealt with the geography of urban design practice, from the sites of elaboration and innovation to those of implementation and application. In accord with the historical making of the field of urban design, the geography as well as the approaches surveyed are significantly dependent on both national and local contexts. ${ }^{1}$ Schools reproduce themselves, so programs that developed early, such as GSD at Harvard or the equivalent at Bartlett-UCL, TU-Delft or ETH-Zurich, have provided cohorts of skilled professionals that have had a serious impact on both the public and private sector. Not only does there appear to be a scholarly pathdependence with a somewhat clear geography, but there is also an urban

\footnotetext{
${ }^{1}$ To build the sample of the University programs, we started from the work by Palazzo on the pedagogical traditions of urban design (2011), which we updated through a web inquiry and an experts inquiry carried out by the jiscmail devoted to urban design. We specifically focused on University programs on urban design. To build the sample of firms we started by analyzing the winners of the American Institute of Architects (AIA) awards, section of urban design, of the last 5 years and few directories partly or entirely devoted to urban design, such as archdaily, laud8, urban design group, dexigner. We also adopted a snowball sample strategy, asking all the firms and academics contacted to signal up to five firms that have been carrying out interesting and/or influential works in the last couple of years. On this basis we contacted more than 29 academics and 62 firms. The result of this first stage of research is a body of 39 recorded interviews carried out in May 2014 and between April and May 2015.
} 
path-dependence. Beside the few gigantic global firms such as SOM, ARUP or HOK (some of which were interviewed) that run offices worldwide and hire thousands of skilled architects and urban designers, most middle to low-size firms are locally embedded in a city in which they get the majority of their commissions and in which they foster their social capital through meetings, conferences and events (Tiesdell and Adams 2011). In a similar way to what was shown by Fainstein on local developers, urban design firms, even when they "go global," have to keep their local roots (2001).

The nexus between globalism and localism is precisely represented by cosmopolitanism, a professional and cultural marker that most of the interviewees pointed to as the crucial element in defining themselves. The architects and designers interviewed all had one point in common, whether they were working in a multinational firm based in New York or a small practice in Stockholm: they were trained in different universities and cities, had multiple professional experiences in several countries, and worked in a culturally diverse and cosmopolitan working environment.

Even though the geography of universities has its own hierarchy, as pointed above, circulation nonetheless defined the working life of each professional we got in touch with:

The language in the office is English because we have a lot of different nationalities, there are Danish people, there are American people, there are Italian people, there are Spanish people...yeah, I think that's it right now. But we have had a lot of different nationalities here...Swedes, Germans...from all over Europe, which I also think is a great strength to getting different kinds of perspective on what they think, or what they know is working where they're from, and how it could work here and also why they think something's not going to work here in that sense. And that's also why I'm so interested in this, because what we do here and the way we work here and the way we try to influence the way that the public space is being developed and how it's being designed, I would really try to share that with different cities and municipalities, try to guide them to how they could sort of do the same kinds of spaces that we do here in Denmark. (Founder, mid-size firm, Copenhagen)

Almost every interview brought out information about internships and the educational, ethnic and national backgrounds of the interviewees, but also attitudes towards travels, open-mindedness and cultural sensitivity that highlighted the quality of a professional cosmopolitan. While we might assume that this cosmopolitan ethos is a common trait for most professionals dealing in a globalized environment (lawyers, managers, doctors, etc.) or for high-skilled people working in global cities, one specificity for architects and urban designers is the role played by field trips.

\subsubsection{Fieldtrips: The Nexus Between Models and Inspiration}

All the interviewees from architecture and urban design firms shared the habit of traveling to other cities and territories to learn from other practices and to visit projects under construction or see finished ones. These activities were part of the professional group activity called the field trip. 
Fieldtrips and relationships among firms contribute to crystallizing views and models, especially in relation to public space design, but also to fostering the sense of being a community of professionals, forging the identity of the global architect and designer.

The issue of models is crucial to understanding contemporary place-making by architects and urban designers. First of all, there is longstanding tradition of "contextualism" in urbanism and architecture, defined by such figures as Camillo Sitte, Colin Rowe, and Aldo Rossi. Under this perspective, which owes a significant debt to studies carried out by Sitte in nineteenth-century Italy to identify the perfect piazza (Der Städtebau nach seinen künstlerischen Grundsätzen was published in 1889), squares were considered the prototypes of qualitative superior urban life. The contextual tradition is renewed constantly through professional fieldtrips, and places like Italy, for instance, play a role as a site of continuous inquiry and learning.

Field trips might also be considered as a professional tourism activity. In the case of Italy, this tourism is informed by a historical context in which aristocrats and nobles scrutinized Southern Europe during the Grand Tour and afterwards (Hom 2015):

\begin{abstract}
We spent the most time in Rome, I really like Rome, and then Lucca, when we were on that trip we were in Lucca for six weeks, and then stopped outside of Pienza, we actually stayed on a farm for a week, just a week, but it was...[...] and so that was really influential, and then to be ... in terms of inspiration, it's kind of, yeah, in the background, that's the kind of place I'd go to be intellectually inspired. (Founder, middle-size firm, San Francisco; emphasis supplied)
\end{abstract}

While there is no socio-political understanding of the contemporary urban condition of Italian cities and squares, a subterranean Orientalism keeps orienting these fieldtrips. In several interviews Southern Europe emerged as a place for cosmopolitan inspiration, while the Global North acted more as a place for cosmopolitan creation and development.

The geography of inspiration may produce moral labels among urban designers that are consistent with an ordering and deciphering activity necessary to foster a cosmopolitan perspective on public spaces. If medieval and Renaissance Italy can act as a place to get "intellectually inspired," one might also consider the other side of the spectrum, namely "shitty places":

And I think you should also go and visit some shitty places, there's so much to visit in Dublin, and see how it looks there, like, places where it's not nice, and I think it would be good to, it would be interesting, [...] but I think places that are, like, like Turkey or India or whatever, that are at the edge of ...China also ...that are not like super-poor countries but how they think public space. (Partner, mid-size firm, Copenhagen)

This differentiation among field trip destinations between "intellectually inspiring" and "shitty" places led Moscow and Berlin to be identified, like Rome, Siena, Ravenna, and Lucca, as interesting starting places, while generally speaking the Global South is more on the "shitty" side.

While the landscape of inspiration follows a Global North/Global South divide, it is also clear that the geography of production goes eastward. The Arabian 
Peninsula, South Korea and, at a higher level, China are the places to go to apply what's being re-learned in Europe and elaborated throughout the Global North:

[in China] I mean, I hate to use this word, but it is a lot more totalitarian, you know, "there are ... some villages here, but we're going to move the people, so don't worry about it" [...] it was almost like there were no limits, you can design what you wanted to design as long as you could get the developer (Partner, multinational firm, New York office).

As a vast country providing territories, possibilities and chances (Ren 2011), China acts as a dreamland for engineers, architects and urban designers. Cosmopolitan landscapes develop quickly here and with ambiguous effects (Söderström 2006). For some urban designers China acts as an elevator-space to get a project done, acquire visibility and develop an international reputation and standing which can be leveraged in the highly competitive urban design field back home (Kennedy 2005). For others, the Far East is a fascinating terrain, though for dubious moral aspects:

Life is easy for China, you know, they just can allocate funds, like... Singapore, I mean, that's fantastic, I mean, who can't do things in Singapore, with an undemocratic city-state? (Partner, multinational firm, Chicago office)

In several interviews, discussing projects in China or the Emirates paved the way for a sort of Western complicity among gentlemen (from an intersectional standpoint: a white (often) male, upper-class, cosmopolitan complicity) which admitted that something nasty was at stake when an eco-friendly, resilient and smart design of a waterfront was developed in a country that did not give women the right to vote or denied basic human rights to foreign workers.

This moral ambiguity has always been a critical aspect of architecture. It has also been part of the history of urban design, if one considers the modernist masterplan of La Havana designed by Luis Sert under Batista's dictatorship in 1955 Cuba (Hyde 2008). What is somewhat new is the global scope and diffusion of urban design today (Punter 2007). As a senior associate in a global-size firm declared:

you know we're building new cities, so urban design is the city, outside of what the specific architecture is; other than opportunities like that, it is still kind of hard to define what it is when you engage in a city that is already built or is a little bit of improvement here and there and is not a tabula rasa like starting from scratch greenfield city-building exercise. (Senior associate, firm with 24 offices worldwide and 1900 worldwide employees; emphasis supplied)

Moral boundary-making is a well-recognized feature of professional cultures (Lamont and Molnar 2002). There are different directions of boundary-making: an external as well as an internal one. The external is devoted in setting the difference between urban design and other fields and professions, namely architecture, landscape architecture and planning. It is a fundamental strategy in order to gain respectability and autonomy towards commissioners and the public, but a very slippery one given the uncertain status of this discipline and the heavy dependence on formal training and education in architecture. Many respondents, for instance, defined themselves as "architects" during presentations or declared that they mostly presented themselves as architects with clients. The second direction of 
boundary-making is an internal one: given the close relationship between urban design and the public space, setting the moral stage for further interventions is a crucial step. While in the academic literature on urban design there is a general confusion with regards to place-making, when we interrogated scholars, we gathered mixed reactions, and some of them were harsh:

I really don't use the word place-making, I think it's retrograde, conservative, nationalist. ... I think place-making is too easy ... it's trivial and suspect...I mean Disney makes places. [...] urban design is the means in which social and cultural transformations are made physically, making manifest in public space. (Academic and practitioner, New York)

Contradictions between the "trivial" aspect of working in the production of serial projects ("Disney makes places") and the craftsman-like or quasi-demiurgical role advocated by the aristocracy of urban designers is a common element of the interviews. Other levels of mismatch between the professional progressive ethos and the mundane working arrangements may be found in the attitude towards communities and community-led design (or participatory-led design) and in the adoption of catchy adjectives such as "resilient" or "smart," which many respondents felt were mostly fashionable buzzwords but nonetheless used them during the interview as well as in their daily practice.

Gentrification, for instance, is clearly an ambivalent outcome to deal with. Some interviewees clearly rejected or adopted a critical perspective towards it, delving in the tradition of community-based participatory design:

I don't think anybody's really solved the displacement or the ...I don't know that it's solvable... the gentrification issue, unfortunately, but I think it's always something at the top of mind for us, and just thinking about what impact the changes we're proposing in for a neighborhood are going to have on the people who are living there, so it's a really important part of [our job]. (Founder, middle-size firm, San Francisco)

Others, more interestingly, adhered to the vision of gentrification as a means of urban regeneration, part of which was linked to urban design:

I don't think there's a specifically Dutch public space, I think they actually do start it now, like Rotterdam when I was there, actually, there was shit in the streets and so many drug dealers and now it's been, again, gentrified and much more focus on like how you treat the ground floor of buildings, that you have some kind of public control, or like, like with a public space, like, and that you get some kind of interaction of the buildings with the public space, also this Jan Gehl kind of dogma, and so ...I think, I actually think right now that a lot, a lot of focus on Denmark, it has to do with very successful architects and like a generation of architects that have been kind of successful doing interesting stuff, it has to do with the municipality being kind of proactive, both in Copenhagen and in Aarhus and in other cities [...] and I always think it's interesting what's going on in Switzerland, also very clean and very nice always that, but still good. And also always with a substantial amount of money there. (Partner, middle-size firm, Rotterdam) 


\subsection{Conclusion}

Urban design is a relatively recent breed in the urbanism tradition with a sharp growth of activities at a global scale. One of the main reasons for that is the rising attention to the issue of public space. While there is no clear definition whatsoever of the concept, public space emerged as a key spatial form in neoliberal urbanism. While cities long for international visibility through cultural regeneration processes, their citizens ask for cosmopolitan, livable and festive environments. Urban design provides this stage. It does so by adopting abstract models of public life settings, such as the Italian piazza, or by accepting the spatial and behavioral determinism of early pioneers such as W. H. Whyte or Jan Gehl. Nonetheless, the voices of these urban designers tell a story of progressive crystallization of a professional field around the idea of a city centered on its public spaces. Urban designers act, among other professionals, as "conveyors of cosmopolitan taste," as Ole Söderström has put it (2006). This is especially true with the kind of urbanity that is under construction in the Far East and Arabian Peninsula, two regions of the world in which cosmopolitan forms are applied in authoritarian cultural and political contexts. This contradiction lies at the heart of the urbanization process and asks for broader investigation and discussion.

Cosmopolitanism, as it emerged from the voices of urban designers, is embedded in both their professional identity (education and career) and their perspective towards their own activities. Living in an international milieu, longing for international careers, urban designers apply models and visions that are cosmopolitan in meaning and scope. When asked about the risk of homogenization that the application of models at various scales implied, a practitioner and scholar responded with a remarkably reflexive account:

yes, there is homogenization, and the homogenization is not necessarily because there is a center of these ideas, where these ideas come from, maybe. But the homogenization comes from, to my mind and having really talked to people from across the world and, you know, in the last twenty-five years traveling a lot and, you know, and teaching and so on and so forth, the homogenization comes out of a desire to take part in a particular type of civilization, right? which is global. And for many people across the world that attempt has a type of esthetic appeal that they believe is a result of design, right? (Academic and practitioner, New York)

If the former reflection stands, then we have a hypothesis for further research agendas: is cosmopolitanism an aesthetics rather than an ethics? Maybe we are not talking anymore about just or unjust societies, but only wondering whether the global order we are producing is beautiful or not (Berleant 2018). Aesthetics as a social and moral category may then become the new frontier of urban inequality and cosmopolitanism its vehicle. 


\section{References}

Alaily-Mattar, N., Ponzini, D., \& Thierstein, A. (Eds.). (2020). About star architecture: Reflecting on cities in Europe. Springer Nature.

Amin, A. (2008). Collective culture and urban public space. City, 12(1), 5-24.

Berleant, A. (2018). Aesthetics and environment: Variations on a theme. New York: Routledge.

Binnie, J., Holloway, J., Millington, S., \& Young, C. (Eds.). (2006). Cosmopolitan Urbanism. Abingdon: Routledge.

Bodnar, J. (2015). Reclaiming public space. Urban Studies, 52(12), 2090-2104.

Fainstein, S. S. (2001). The city builders: Property development. In New York and London, 1980-2000. Lawrence: University Press of Kansas.

Gehl, J. (2011). Life between buildings: Using public space. Washington, DC: Island Press.

Gospodini, A. (2002). European cities in competition and the new 'uses' of Urban Design. Journal of Urban Design, 7(1), 59-73.

Graham, S., \& Marvin, S. (2001). Splintering Urbanism: Networked infrastructures, technological mobilities and the urban condition. London: Psychology Press.

Hackworth, J., \& Smith, N. (2001). The changing state of gentrification. Tijdschrift Voor Economische en Sociale Geografie, 92(4): 464-477.

Hannigan, J. (2005). Fantasy City: Pleasure and profit in the postmodern Metropolis. London: Routledge.

Harvey, D. (2011). The enigma of capital and the crises of capitalism. London: Profile Books.

Hom, S. M. (2015). The beautiful country: Tourism and the impossible state of destination Italy. Toronto: University of Toronto Press.

Hubbard, P. (1996). Urban Design and City regeneration: Social representations of entrepreneurial landscapes. Urban Studies, 33(8), 1441-1461.

Hyde, T. (2008). Planos, Planes y Planification: Josep Lluís Sert and the Idea of Planning. In E. Mumford \& H. Sarkis (Eds.), Josep Lluís Sert: The architect of urban design, 1953-1969 (pp. 54-75). New Haven: Yale University Press.

Jessop, B. (1993). Towards a Schumpeterian workfare state? Preliminary remarks on post-Fordist political economy. Studies in Political Economy, 40(1), 7-39.

Julier, G. (2005). Urban Designscapes and the production of aesthetic consent. Urban Studies, 42.5(6), 869-887.

Kennedy, P. (2005). Joining, constructing and benefiting from the global workplace: Transnational professionals in the building design industry. The Sociological Review, 53(1), 172-197.

King, A. D. (2004). Spaces of global cultures: Architecture, Urbanism, identity. London: Routledge.

Lamont, M., \& Molnár, V. (2002). The study of boundaries in the social sciences. Annual Review of Sociology, 28(1), 167-195.

Lees, L., Slater, T., \& Wyly, E. (2013). Gentrification. London: Routledge.

Madanipour, A. (2006). Roles and challenges of urban design. Journal of Urban Design, 11(2), 173-193.

Marshall, R. (2009). The elusiveness of urban design: The perpetual problem of definition and role. In A. Krieger \& W. S. Saunders (Eds.), Urban design (pp. 38-57). Minneapolis: University of Minnesota Press.

McCann, E., \& Ward, K. (Eds.). (2011). Mobile urbanism: Cities and policymaking in the global age. Minneapolis: University of Minnesota Press.

Mitchell, D. (2003). The right to the City: Social justice and the fight for public space. New York: Guilford Press.

Moulaert, F., Rodríguez, A., \& Swyngedouw, E. (Eds.). (2003). The globalized city: Economic restructuring and social polarization in European cities. Oxford: Oxford University Press.

Mumford, E. P. (2009). Defining urban design: CIAM architects and the formation of a discipline, 1937-69. New Haven: Yale University Press. 
Peck, J., \& Theodore, N. (2010). Mobilizing policy: Models, methods, and mutations. Geoforum, 41(2), 169-174.

Peck, J., \& Theodore, N. (2015). Fast policy: Experimental statecraft at the thresholds of neoliberalism. Minneapolis: University of Minnesota Press.

Ponzini, D. (2014). The values of starchitecture: commodification of architectural design in contemporary cities. Organizational Aesthetics, 3(1), 10-18.

Ponzini, D., \& Nastasi, M. (2016). Starchitecture: Scenes, actors, and spectacles in contemporary cities. New York: The Monacelli Press.

Punter, J. (2007). Developing urban design as public policy: Best practice principles for design review and development management. Journal of Urban Design, 12(2), 167-202.

Ren, X. (2011). Building globalization: Transnational architecture production in urban China. University of Chicago Press.

Rossi, U. (2017). Cities in global capitalism. Chichester: Wiley.

Schurch, T. W. (1999). Reconsidering Urban design: Thoughts about its definition and status as a field or profession. Journal of Urban Design, 4(1), 5-28.

Semi, G. (2015). Gentrification: tutte le Città come Disneyland? Bologna: Il mulino.

Semi, G., \& Bolzoni M. (2020). Star architecture and the field of urban design. In N. AlailyMattar, D. Ponzini, \& A. Thierstein (Eds.), About star architecture: Reflecting on cities in Europe (pp. 55-67). Berlin: Springer.

Sitte, C. (1889). Der Städtebau nach seinen Künstlerischen Grundsätzen. Auflage.

Sklair, L. (2005). The transnational capitalist class and contemporary architecture in globalizing cities. International Journal of Urban and Regional Research, 29(3), 485-500.

Söderström, O. (2006). Studying cosmopolitan landscapes. Progress in Human Geography, 30(5), 553-558.

Sorkin, M. (1992). Variations on a theme park: The new American city and the end of public space. New York: Macmillan.

Sorkin, M. (2009). The end(s) of urban design. In A. Krieger \& W. S. Saunders (Eds.), Urban design (pp. 155-182). Minneapolis: University of Minnesota Press.

Tiesdell, S., \& Adams, D. (2011). Urban design in the real estate development process. Chichester: Wiley.

Young, C., Diep, M., \& Drabble, S. (2006). Living. with Difference? The 'Cosmopolitan City' and Urban Reimaging in Manchester, UK. Urban Studies, 43(10), 1687-1714.

Zukin, S. (1995). The cultures of cities. London: Blackwell.

Open Access This chapter is licensed under the terms of the Creative Commons Attribution 4.0 International License (http://creativecommons.org/licenses/by/4.0/), which permits use, sharing, adaptation, distribution and reproduction in any medium or format, as long as you give appropriate credit to the original author(s) and the source, provide a link to the Creative Commons license and indicate if changes were made.

The images or other third party material in this chapter are included in the chapter's Creative Commons license, unless indicated otherwise in a credit line to the material. If material is not included in the chapter's Creative Commons license and your intended use is not permitted by statutory regulation or exceeds the permitted use, you will need to obtain permission directly from the copyright holder.

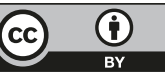

